\title{
Comparing the Result of Infrastructure and Facility Demand Distribution Similarity Test between Using Percentage Value and Real Value
}

\author{
Hitapriya Suprayitno ${ }^{1, a)}$, Vita Ratnasari ${ }^{2, b)}$ \& Ria Asih Aryani Soemitro ${ }^{1, c)}$ \\ ${ }^{1)}$ Dept. of Civil Engineering, Institut Teknologi Sepuluh Nopember (ITS), Surabaya, Indonesia. \\ ${ }^{2)}$ Dept. of Statistics, Institut Teknologi Sepuluh Nopember (ITS), Surabaya, Indonesia. \\ Correspondent : ${ }^{a}$ suprayitno.hita@gmail.com, ${ }^{b}$ vitaratna70@gmail.com \& ${ }^{c}$ ria@ce.its.ac.id.
}

\begin{abstract}
Understanding the Infrastructure \& Facility Demand Behaviour is important. Sometimes, comparing two Demand Behaviour need to be done. A method to make Distribution Similarity test has been developed for Transportation Trip Length Distribution Similarity test. This test can be used for comparing Infrastructure \& Facility Demand Behavior. There are still questions on whether the test must be made upon the Distribution of Real Value or upon the Distribution of Percentage Value. The research result indicates that Comparing Distribution Similarity must use Distribution Percentage Value. The similarity must be measured based on Accepted Goodness of Fit measured in $\chi^{2}$ Value, and Accepted Difference Value measured in Absolute Difference Value.
\end{abstract}

Keyword : infrastructure \& facility asset management, demand behavior, distribution similarity test.

\section{INTRODUCTION}

In Infrastructure \& Facility Asset Management (IFAM), Demand Behavior need to be well understood. Infrastructure \& Facility (I\&F) Planning, Design, and Operation must be developed, made and executed in accordance to the I\&F Demand. Either the actual demand or the predicted demand, it depends on the case treated (Chilongola et al, 2020; Hamzah et al, 2020; Soemitro \& Suprayitno, 2018; Suprayitno et al, 2006; Suprayitno \& Soemitro, 2018; Suprayitno, 2020; Susanti et al, 2017; Upa \& Setyadi, 2020; Valguna et al, 2020).

In I\&F Demand Behavior Analysis, a lot of time, it is necessary to compare the Distribution of a Demand Behavior Characteristics between a certain case to another case. Examples of comparaison items can be on distribution of passenger ages, distribution of passenger genders, distribution of passenger occupation, distribution of passenger education level, distribution of trip purpose, distribution of travel distances, distribution of mode utilization, etc (Avecedo \& Nohara, 2004; Suprayitno, Pambudi \& Cahyono, 2017; Susanti et al, 2019; Susanti et al, 2020; Upa et al, 2018).

A method for Distribution Comparaison has been developed in Transportation Demand Modeling. This method is designated for determining the Minimum Number Sample for Trip Length Distribution Survey. Based on Goodness of Fit Statistical Test, the Number of Sample can be calculated. This is a trial-and-error method. The Demand Characteritics Similarity is measured based on Accepted CP\&EV (Curve Pattern and Error Value), by using Goodness of Fit Statistical Test combined with an Error Acceptance Test (Blank, 1982; Siegel, 1956; Suprayitno, Ratnasari \& Saraswati, 2017).

Certainly, this method can be used for comparing I\&F Demand Behaviour Characteristics. But, to be used for IFAM Demand Behavior comparaison, in general, the 
method name should be changed into Accepted Curve Pattern Similarity and Absolute Value Difference (CPS+AVD).

The author, sometimes, are still questioned by the students, the researchers, or the academicians on the type of data, the calculation should be based on. The calculation should be based on the distribution value in percentage value or on the real value. The answer needs to be investigated.

This paper presents the investigation of distribution similarity test by using percentage distribution value and real distribution value.

\section{RESEARCH METHOD}

This research method is to investigate whether, in distribution similarity testing, it is better to use Real Value Distribution or Percentge Value Distribution. The Method of Accepted CP\&EV was used to execute the investigation. Two Cases were tested, i.e. a Special Case and the Previous Work Case. The experiment upon two cases were finalized by a conclusion.

\section{COMPARAISON ANALYSIS}

\section{Experiment Objective}

The experiment objective is to investigate whether, in case of comparing distribution characteristics similarity, is it necessary to use distribution on percentage value or to use distribution on real value.

\section{Statistical Test for Comparing Two Distributions}

Problem of Comparing the Similarity of Two Distributions is part of Statistical Inference. Two groups of Statistical Literatures are refered. It is written in these two groups of literatures that investigating Similarity of Two Distributions must use the same $\chi^{2}$ Test. But there are certain differences between the two groups (Blank, 1982; Siegel, 1956; Engmann \& Cousineau, 2011; Susetyo, 2010; Siregar, 2016; Purwanto \& Sulistyastuti, 2017).

A statistical literature, a refered book, discussing the matter as a problem of Statistical Inference, called Goodness-of-Fit. It is about investigating whether two Discrete Distributions are from the same distributions or not. The test used is the $\chi^{2}$ Goodness of Fit test. Where calculated $\chi^{2}=\Sigma\left(\left(\mathrm{y}_{\mathrm{o}}-\mathrm{y}_{\mathrm{r}}\right)^{2} / \mathrm{y}_{\mathrm{r}}\right)$, with $\mathrm{df}=\mathrm{k}-\mathrm{r}-1$ (Blank, 1982). A research has been done to compare two different tests for investigating the non-parametric distribution similarity. The two tests involved are the Anderson-Darling Test and the Kolmogorov-Smirnoff test. The research concluded that the the Anderson-Darling Test is more powerful than the Kolmogorov-Smirnoff test (Engmann \& Cousineau, 2011).

In three refered Indonesian Statistical Books, the Statistical Tests to investigate the similarity of a Sample Distribution to the Reference Distribution are explained. It can be said that the data is classified as nominal data expressing categorical data or frequency data. Thus, the statistical test is to check whether the Observed Frequency is the same or not to the Expected Frequency. It is tested by using $\chi^{2}$ test. Where calculated $\chi^{2}=\Sigma\left(\left(\mathrm{f}_{\mathrm{o}}-\mathrm{f}_{\mathrm{e}}\right)^{2} / \mathrm{f}_{\mathrm{e}}\right)$ with $\mathrm{df}=\mathrm{n}-1$. As example, the three books explain the comparaison between Obsereved Frequency compared to Expected Uniform Frequency, as a special case of Two Distribution comparaison (Susetyo, 2010; Siregar, 2016; Purwanto \& Sulistyastuti, 2017).

\section{Previous Works}

\section{$\underline{\text { Travel and Tourism Behavior Characteristics Comparaison }}$}

A lot of researches on Travel and Tourism Behaviour Characteristics have been done. Several of them can be mentioned as follows: urban bus travel behavior characteristics, commuter train travel behavior characteristics, tourism voyage characteristics, and others. 
Apart from those, comparaison on travel and tourism behavior have been done. Among others, a comparison between Trans Maminasata and Trans Koetaradja user trip behaviors, a comparaison of influence area for motorcycle trip, a comparaison of tourism voyage characeristics between the young voyagers nd senior voyagers (Avecedo \& Nohara, 2004; Suprayitno, Pambudi \& Cahyono, 2017; Susanti et al, 2019; Susanti et al, 2020; Upa et al, 2018).

\section{Distribution Similarity Test}

A method to compare Distribution Similarity has been developed. This method is designated for determining the Minimum Sample Size. According to the Statistical Theory, the Distribution Similarity must be checked bu using Goodness of Fit test based on $\chi^{2}$ test. But experiments indicate that sometimes even if the result of the Goodness-of- Fit is good, the Error can still be high enough. Therefore, the Distribution Similarity for that purpose is added by Accepted Error Value test, based on mean absolute error. Those two tests are presented as follows (Suprayitno, Ratnasari \& Saraswati, 2017; Suprayitno et al, 2018).

\section{Goodness-of-Fit Test}

Goodness of Fit test is a statistical test to investigate whether two Distributions can be considered as the same Distributions or not. The test used is the $\chi^{2}$ test. The Goodness of Fit test is presented as follows (Suprayitno, Ratnasari \& Saraswati, 2017; Suprayitno et al, 2018).

$\mathrm{H}_{0}:$ if $\chi^{2}<\chi^{2}{ }_{0}$, the two Distributions are the same.

$\mathrm{H}_{1}$ : if $\chi^{2}>\chi^{2}$, the two Distributions are not the same.

$\chi^{2}=\sum \frac{\left(y_{i}-y_{i}^{0}\right)}{y_{i}^{0}}$

$\chi_{0}^{2}=\chi_{(v, \alpha)}^{2}$

$v=n-k-1$

Where :

$\chi^{2}=$ calculated $\chi^{2}$ value.

$\chi^{2}{ }_{0}=$ reference $\chi^{2}$ value, on certain degree of freedom and significance level.

$\mathrm{y}^{\mathrm{i}}=$ the tested $\mathrm{y}$ value

$\mathrm{y}_{0}{ }^{\mathrm{i}}=$ the reference $\mathrm{y}$ value

$\mathrm{n} \quad=$ number of samples

$\mathrm{k} \quad=$ number of cases

$v \quad=$ degree of freedom

$\alpha \quad=$ significance level

\section{Acceptable Error Value Test}

Acceptable Error Value test is to investigate whether the Absolute Error of the Sample Distributions, compared to the reference distribution, is acceptable or not. Error of $2 \%, 5 \%$ or $10 \%$ are normally used as an acceptable threshold, depend on the case (Suprayitno, Ratnasari \& Saraswati, 2017; Suprayitno et al, 2018).

$\mathrm{H}_{0}$ : if $|\bar{e}|<\mathrm{e}_{0}$, the error is accepted.

$\mathrm{H}_{1}$ : if $|\bar{e}|>\mathrm{e}_{0}$, the error is not accepted.

$|\bar{e}|=\frac{\sum\left|e_{i}\right|}{n}$

$\left|e_{i}\right|=\frac{\left|y_{i}-y_{i}^{0}\right|}{y_{i}^{0}}$ 
Where :

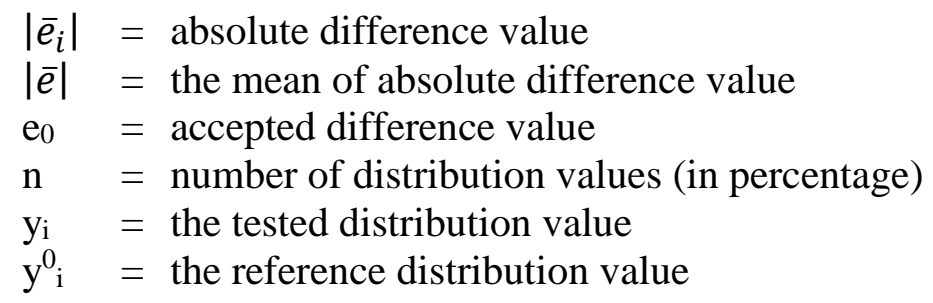

\section{Research Cases}

In order to get a clear explanation of the problem, for this research, two cases were taken and investigated. Those are the Special Case and the Previous Case (Suprayitno, Ratnasari \& Saraswati, 2017) taken from the Previous Work. The Special Case were a fictive case, consists of 1 Reference Population and 3 other populations, those 4 have exactly the same Precentage Value Distribution but different Number of Population. The Previous Case was taken from he case used for writing paper on Method for Determining the Minimum Number of Sample for Transportation Trip Length Modeling Survey.

\section{Special Sampling Case Experiment}

A Special Case was taken for investigating the difference of using the Real Value Distribution and the Percentage Value Distribution. A Reference Population has a population of 200 events with a Certain Distribution in 4 Catagorical Values. Three Special Sampling were taken with three different sample sizes of 200 events, 150 events, and 100 events. The sampling was done in a such special way, that the Distribution Proportion is exactly the same as the Reference Population. It can be imagined that this kind of situation, logically, is possible to occur. Two Distribution Values are calculated for those Reference and Three Sample cases, one is based on Real Value and the other is based on Percentage Value. The Distributions are presented in Table 1 as follows.

Table 1. Distribution of the Special Sampling Cases

\begin{tabular}{|c|c|c|c|c|c|c|c|c|c|}
\hline \multirow{2}{*}{ No } & \multirow{2}{*}{ Category } & \multicolumn{6}{|c|}{ Dis tribution in Real Value } & \multicolumn{3}{|c|}{ Distribution in Percentage Value } \\
& & Ref. & A & B & C & Ref. & A & B & C \\
\hline 1 & very hard & 20 & 20 & 15 & 10 & $10 \%$ & $10 \%$ & $10 \%$ & $10 \%$ \\
\hline 2 & hard & 80 & 80 & 60 & 40 & $40 \%$ & $40 \%$ & $40 \%$ & $40 \%$ \\
\hline 3 & soft & 60 & 60 & 45 & 30 & $30 \%$ & $30 \%$ & $30 \%$ & $30 \%$ \\
\hline 4 & very soft & 40 & 40 & 30 & 20 & $20 \%$ & $20 \%$ & $20 \%$ & $20 \%$ \\
\hline & & 200 & 200 & 150 & 100 & $100 \%$ & $100 \%$ & $100 \%$ & $100 \%$ \\
\hline
\end{tabular}

Afterward, the distributions of the three samples were test against the Reference Distribution, to check whether those three Samples are from the same distribution as the Reference or not. The Similarity Distribution Test (Goodness of Fit and Error Value tests) upon Real Value Distribution gave bad value of $\chi^{2}$ and Error. Those, Distribution of Sample A is the same as the Distribution of the Reference. The test upon Sample B and Sample C indicate gave a bad value of $\chi^{2}$ and Error. Those, the Disribution of Sample B and Sample C are not the same as the Distribution of the Reference. The calculation is presented in Table 2 as follow. 
Table 2. Distribution Similarity Test for the Distribution of Real Value

\begin{tabular}{|c|c|c|c|c|c|c|c|c|c|c|}
\hline \multirow{2}{*}{ No } & \multicolumn{4}{|c|}{ Distribution in Real Value } & \multicolumn{3}{|c|}{$\chi^{2}$ Calculation } & \multicolumn{3}{|c|}{ Difference } \\
\hline & Ref. & $\mathbf{A}$ & $\mathbf{B}$ & $\mathbf{C}$ & $\mathbf{A}$ & $\mathbf{B}$ & $\mathbf{C}$ & $\mathbf{A}$ & $\mathbf{B}$ & $\mathbf{C}$ \\
\hline 1 & 20 & 20 & 15 & 10 & 0,000 & 1,250 & 5,000 & $0 \%$ & $25 \%$ & $50 \%$ \\
\hline 2 & 80 & 80 & 60 & 40 & 0,000 & 5,000 & 20,000 & $0 \%$ & $25 \%$ & $50 \%$ \\
\hline 3 & 60 & 60 & 45 & 30 & 0,000 & 3,750 & 15,000 & $0 \%$ & $25 \%$ & $50 \%$ \\
\hline \multirow[t]{2}{*}{4} & 40 & 40 & 30 & 20 & 0,000 & 2,500 & 10,000 & $0 \%$ & $25 \%$ & $50 \%$ \\
\hline & 200 & 200 & 150 & 100 & & & & & & \\
\hline & & & & & 0,000 & 12,500 & 50,000 & $0 \%$ & $25 \%$ & $50 \%$ \\
\hline & & & & & \multicolumn{3}{|c|}{ getting worse } & \multicolumn{3}{|c|}{ getting worse } \\
\hline
\end{tabular}

The Distribution Similarity Tests (Goodness of Fit and Difference Value tests) on the Distribution of Percentage Values, indicate that the test on Distribution of Percentage Value gave conclusions that all of the three Special Samples (A, B, and C) has the same Distribution Pattern as the one of the Reference Distribution. The test Result is much more logical than the test before, based on Distriution of Real Value. The test calculation is presented in Table 3 as follows.

Table 3. Distribution Similarity Test for the Distribution of Percentge Value

\begin{tabular}{|c|c|c|c|c|c|c|c|c|c|c|}
\hline \multirow{2}{*}{ No } & \multicolumn{4}{|c|}{ Dis tribution in Pe rcentage Value } & \multicolumn{3}{|c|}{ x2 Calculation } & \multicolumn{3}{|c|}{ Difference } \\
\hline & Ref. & $\mathbf{A}$ & $\mathbf{B}$ & $\mathbf{C}$ & $\mathbf{A}$ & $\mathbf{B}$ & $\mathbf{C}$ & $\mathbf{A}$ & $\mathbf{B}$ & $\mathbf{C}$ \\
\hline 1 & $10 \%$ & $10 \%$ & $10 \%$ & $10 \%$ & $0 \%$ & $0 \%$ & $0 \%$ & $0 \%$ & $0 \%$ & $0 \%$ \\
\hline 2 & $40 \%$ & $40 \%$ & $40 \%$ & $40 \%$ & $0 \%$ & $0 \%$ & $0 \%$ & $0 \%$ & $0 \%$ & $0 \%$ \\
\hline 3 & $30 \%$ & $30 \%$ & $30 \%$ & $30 \%$ & $0 \%$ & $0 \%$ & $0 \%$ & $0 \%$ & $0 \%$ & $0 \%$ \\
\hline \multirow[t]{2}{*}{4} & $20 \%$ & $20 \%$ & $20 \%$ & $20 \%$ & $0 \%$ & $0 \%$ & $0 \%$ & $0 \%$ & $0 \%$ & $0 \%$ \\
\hline & $100 \%$ & $100 \%$ & $100 \%$ & $100 \%$ & & & & & & \\
\hline & & & & & $0 \%$ & $0 \%$ & $0 \%$ & $0 \%$ & $0 \%$ & $0 \%$ \\
\hline & & & & & \multicolumn{3}{|c|}{ exactly the same } & \multicolumn{3}{|c|}{ exactly the same } \\
\hline
\end{tabular}

This special phenomen, that the Test Results are different between by using Distribution of Real Value and by using Distribution of Percentage Value can be explained through Figure 1 and Table 4 as follows. The Real Value Distribution Case has 3 different Distribution Graph. In fact, those three graphs have the same pattern but different values. Those give three different Distributions. While, the Distributions of Percentage Value, those three have exactly the same Distribution Values, measured in Percentage. The three graphs are exactly the same (see Fig. 1). The two Test Results are summarized in Table 4.

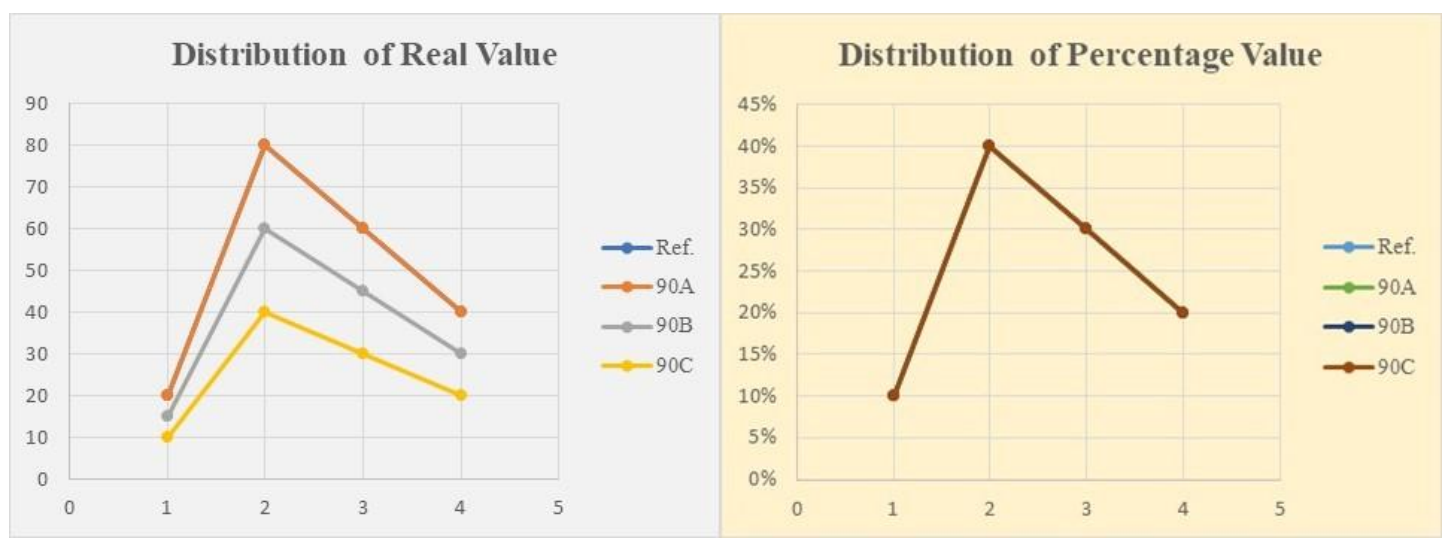

Figure 1. Graph of Distribution Comparison based on Real Value and Percentge Value 
Table 4. Summary of Special Smpaling Case Experiment

\begin{tabular}{|c|c|c|c|c|c|}
\hline \multirow{2}{*}{ No } & \multirow{2}{*}{ Sample } & \multicolumn{2}{|c|}{ Real Value } & \multicolumn{2}{c|}{ Percentage Value } \\
\cline { 3 - 6 } & & $\chi \mathbf{2}$ Value & Difference & $\chi^{2}$ Value & Difference \\
\hline & & & $\%$ & & $\%$ \\
\hline 1 & A & 0,0 & $0 \%$ & 0,0 & $0 \%$ \\
\hline 2 & B & 12,5 & $25 \%$ & 0,0 & $0 \%$ \\
\hline 3 & C & 25,0 & $50 \%$ & 0,0 & $0 \%$ \\
\hline
\end{tabular}

It can be concluded that, Comparing Distribution Pattern Similarity must be based on the Distribution of Percentage Value. The Distribution of Real Value can be used only and absolutely only when Sample Size is the same as those of Reference Distribution.

\section{Experiment on Previous Sampling Case}

The Previos Case, used to develop the Method for Determining Minimum Sample Size, was retested by using Distributions of Real Value. Then, the test results were compared, between by using Distribution of Percentage Value and by using Distribution of Real Value. Four Distribution Similarity Tests were taken for the 90\%, 80\%, 70\%, and 60\% Samples. For each Percentage sample, 3 different samples were taken (Suprayitno, 2017). The experiment written above indicates that, for this case, using Distribution of Percentage Value give better result.

For this experiment, the Error Difference cannot be compared, since the two tests use different unity value. The previous calculation used percentage unity, while the new calculations are in number.

New calculation results based on Distribution of Real Value for the 90\% Sample Case are presented in Table 5 as follows. It can be seen that, for all of three cases 90A, 90B, and 90C, all of $\chi^{2}$ calculations give higher value compared to those of calculated based on Percentage Value. These indicate that calculation based on Distribution of Percentage Value give more accurate $\chi^{2}$ value than those calculated based on Distribution of Real Value.

Table 5. Distribution Similarity Test - Previous Case 90\% Sample

\begin{tabular}{|c|c|c|c|c|c|c|c|c|c|c|}
\hline \multirow[t]{2}{*}{ No } & \multicolumn{4}{|c|}{ Dis tribution } & \multicolumn{3}{|c|}{$\chi^{2}$ Calculation } & \multicolumn{3}{|c|}{ Diffe re nce } \\
\hline & Pop & 90A & 90B & $90 \mathrm{C}$ & 90A & 90B & $90 \mathrm{C}$ & 90A & 90B & $90 \mathrm{C}$ \\
\hline 1 & 20 & 18 & 17 & 17 & 0.200 & 0.450 & 0.450 & 0.100 & 0.150 & 0.150 \\
\hline 2 & 21 & 19 & 20 & 19 & 0.190 & 0.048 & 0.190 & 0.095 & 0.048 & 0.095 \\
\hline 3 & 8 & 7 & 7 & 8 & 0.125 & 0.125 & 0.000 & 0.125 & 0.125 & 0.000 \\
\hline \multirow[t]{3}{*}{4} & 1 & 1 & 1 & 1 & 0.000 & 0.000 & 0.000 & 0.000 & 0.000 & 0.000 \\
\hline & 50 & 45 & 45 & 45 & & & & & & \\
\hline & & & & 5.99 & 0.515 & 0.623 & 0.640 & 0.080 & 0.081 & 0.061 \\
\hline & & & & & $\mathbf{o k}$ & $\mathbf{o k}$ & $\mathbf{o k}$ & & & \\
\hline \multicolumn{5}{|c|}{ Based on Percentage Distribution Value } & 0.031 & 0.288 & 0.344 & 0.500 & 0.330 & 2.900 \\
\hline & & & & & better & better & better & \multicolumn{3}{|c|}{ uncomparable } \\
\hline
\end{tabular}

The calculation of Distribution Similarity Test for the $80 \%$ Sample Case is presented in Table 6 as follows. Again, the calculated $\chi^{2}$ values for Real Value Distribution are worse then the calculated $\chi^{2}$ for Percentage Value Distribution. Even, according to the Test, the Distribution of the three $80 \%$ Samples are similar to the Distribution of Reference. 
Table 6. Distribution Similarity Test - Previous Case 80\% Sample

\begin{tabular}{|c|c|c|c|c|c|c|c|c|c|c|}
\hline \multirow{2}{*}{ No } & \multicolumn{4}{|c|}{ Distribution } & \multicolumn{3}{|c|}{$\chi^{2}$ Calculation } & \multicolumn{3}{|c|}{ Difference } \\
\hline & Pop & $80 A$ & $80 B$ & $80 \mathrm{C}$ & $80 \mathrm{~A}$ & $80 B$ & $80 \mathrm{C}$ & $90 \mathrm{~A}$ & 90B & $90 \mathrm{C}$ \\
\hline 1 & 20 & 18 & 15 & 15 & 0,200 & 1,250 & 1,250 & 0,100 & 0,250 & 0,250 \\
\hline 2 & 21 & 17 & 17 & 16 & 0,762 & 0,762 & 1,190 & 0,190 & 0,190 & 0,238 \\
\hline 3 & 8 & 4 & 7 & 8 & 2,000 & 0,125 & 0,000 & 0,500 & 0,125 & 0,000 \\
\hline \multirow[t]{4}{*}{4} & 1 & 1 & 1 & 1 & 0,000 & 0,000 & 0,000 & 0,000 & 0,000 & 0,000 \\
\hline & 50 & 40 & 40 & 40 & & & & & & \\
\hline & & & & 5,99 & 2,962 & 2,137 & 2,440 & 0,198 & 0,141 & 0,122 \\
\hline & & & & & ok & ok & ok & & & \\
\hline \multicolumn{5}{|c|}{ Based on Percentage Distribution Value } & 3,006 & 0,428 & 1,376 & 7,5 & 2,8 & 6 \\
\hline & & & & & worse & better & better & \multicolumn{3}{|c|}{ incomparable } \\
\hline
\end{tabular}

Distribution Similarity Test calculation for the $70 \%$ sample is presented in Table 7 as follows. Again, similar as before, all of $\chi^{2}$ calculation result are worse, except for the $70 \mathrm{~A}$ sample. It can be said that Distribution Similarity Test for Real Value Distribution gave a worse result than those of the Percentage Value Distribution.

Table 7. Distribution Similarity Test - Previos Case 70\%

\begin{tabular}{|c|c|c|c|c|c|c|c|c|c|c|}
\hline \multirow[t]{2}{*}{ No } & \multicolumn{4}{|c|}{ Distribution } & \multicolumn{3}{|c|}{$\chi^{2}$ Calculation } & \multicolumn{3}{|c|}{ Difference } \\
\hline & Pop & 70A & $70 B$ & $70 \mathrm{C}$ & $70 \mathrm{~A}$ & $70 B$ & $70 \mathrm{C}$ & 90A & 90B & $90 \mathrm{C}$ \\
\hline 1 & 20 & 15 & 14 & 13 & 1,250 & 1,800 & 2,450 & 0,250 & 0,300 & 0,350 \\
\hline 2 & 21 & 17 & 16 & 14 & 0,762 & 1,190 & 2,333 & 0,190 & 0,238 & 0,333 \\
\hline 3 & 8 & 3 & 4 & 7 & 3,125 & 2,000 & 0,125 & 0,625 & 0,500 & 0,125 \\
\hline \multirow[t]{4}{*}{4} & 1 & 0 & 1 & 1 & 1,000 & 0,000 & 0,000 & 1,000 & 0,000 & 0,000 \\
\hline & 50 & 35 & 35 & 35 & & & & & & \\
\hline & & & & 5,99 & 6,137 & 4,990 & 4,908 & 0,516 & 0,260 & 0,202 \\
\hline & & & & & $\mathbf{x}$ & ok & ok & & & \\
\hline \multicolumn{5}{|c|}{ Based on Percentage Distribution Value } & 6,670 & 2,063 & 1,710 & 11,300 & 5,400 & 6,100 \\
\hline & & & & & worse & better & better & \multicolumn{3}{|c|}{ incomparable } \\
\hline
\end{tabular}

The $\chi^{2}$ Calculation for the $60 \%$ Sample can be seen in Table 8 as follows. The $\chi^{2}$ calculation results for Real Value Distribution are all worse compare to the $\chi^{2}$ value for Percentage Value Distribution.

Table 8. Distribution Similarity Test - Previous case $60 \%$

\begin{tabular}{|c|c|c|c|c|c|c|c|c|c|c|}
\hline No & \multicolumn{4}{|c|}{ Distribution } & \multicolumn{3}{|c|}{$\chi^{2}$ Calculation } & \multicolumn{3}{|c|}{ Difference } \\
\hline & Pop & $60 \mathrm{~A}$ & $60 B$ & $60 \mathrm{C}$ & $60 \mathrm{~A}$ & $60 \mathrm{~B}$ & $60 \mathrm{C}$ & 90A & 90B & $90 \mathrm{C}$ \\
\hline 1 & 20 & 14 & 13 & 10 & 1,800 & 2,450 & 5,000 & 0,300 & 0,350 & 0,500 \\
\hline 2 & 21 & 13 & 12 & 13 & 3,048 & 3,857 & 3,048 & 0,381 & 0,429 & 0,381 \\
\hline 3 & 8 & 3 & 4 & 6 & 3,125 & 2,000 & 0,500 & 0,625 & 0,500 & 0,250 \\
\hline \multirow[t]{4}{*}{4} & 1 & 0 & 1 & 1 & 1,000 & 0,000 & 0,000 & 1,000 & 0,000 & 0,000 \\
\hline & 50 & 30 & 30 & 30 & & & & & & \\
\hline & & & & 5,99 & 8,973 & 8,307 & 8,548 & 0,576 & 0,320 & 0,283 \\
\hline & & & & & $\mathrm{x}$ & $\mathrm{x}$ & $\mathrm{x}$ & & & \\
\hline \multicolumn{5}{|c|}{ Based on Percentage Distribution Value } & 5,412 & 1,803 & 3,142 & 39,300 & 25,000 & 28,700 \\
\hline & & & & & worse & worse & worse & \multicolumn{3}{|c|}{ incomparable } \\
\hline
\end{tabular}


The summary of those four $\chi^{2}$ calculation results are presented in Table 9 as follows. It can be seen that the $\chi^{2}$ based on Percentage Distribution are better than $\chi^{2}$ based on Real Value Distribution. Similar to the first experiment, it can be concluded that comparing Distribution Similarity must be executed based on the Distribution of Percentage Value. This can not be donne based on Real Value Distribution.

Table 9. Summary of Previous Case Experiment

\begin{tabular}{|l|c|c|c|}
\hline & \multicolumn{3}{|c|}{$\chi^{2}$ Value } \\
\hline $\mathbf{9 0 \%}$ Sample & $\mathrm{A}$ & $\mathrm{B}$ & $\mathrm{C}$ \\
by Value & 0.515 & 0.623 & 0.640 \\
by Percentage & 0.031 & 0.288 & 0.344 \\
& worse & worse & worse \\
\hline $\mathbf{8 0 \%}$ Sample & $\mathrm{A}$ & $\mathrm{B}$ & $\mathrm{C}$ \\
by Value & 2.962 & 2.137 & 2.440 \\
\hline by Percentage & 3.006 & 0.428 & 1.376 \\
\hline $\mathbf{7 0 \%}$ Sample & $\mathrm{A}$ & $\mathrm{B}$ & $\mathrm{C}$ \\
\hline by Value & 6.137 & 4.990 & 4.908 \\
\hline by Percentage & 6.670 & 2.063 & 1.710 \\
& better & worse & worse \\
\hline $\mathbf{6 0 \%}$ Sample & $\mathrm{A}$ & $\mathrm{B}$ & $\mathrm{C}$ \\
by Value & 8.973 & 8.307 & 8.548 \\
by Percentage & 5.412 & 1.803 & 3.142 \\
& worse & worse & worse \\
\hline
\end{tabular}

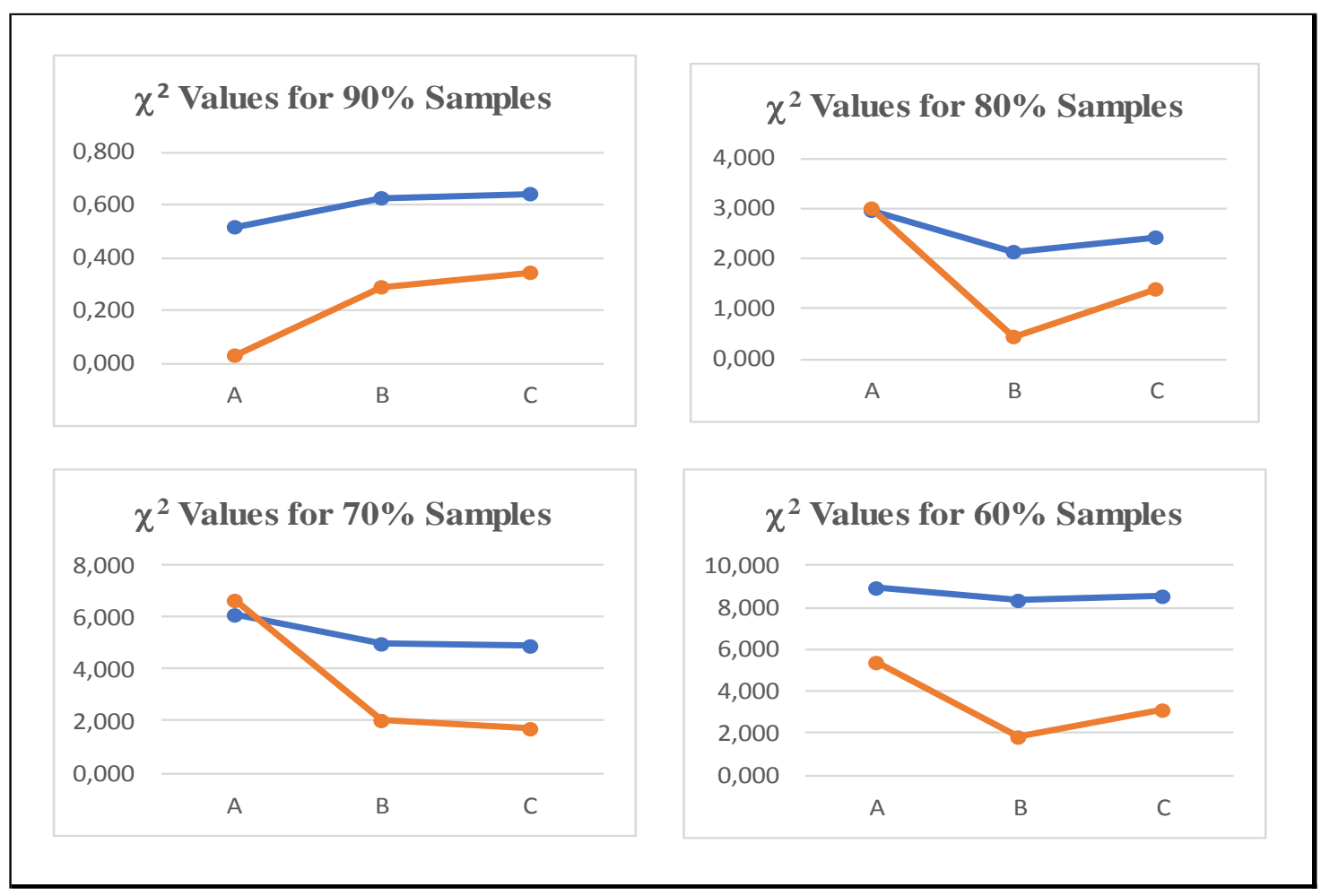

Figure 2. Graph of Various $\chi^{2}$ Value Comparaison 


\section{CONCLUSION} follows.

As, the research have been finished, several principal conclusions are presented as

- Comparing Distribution Similarity must be based on accepted Curve Pattern Similarity (CPS) test and accepted Average Difference Value (ADV) test.

- The aceepted CPS test is done by using $\chi^{2}$ Goodness of Fit test (with significant value of $1 \%-10 \%)$, and the accepted ADV test is done by using the accepted average absolute value (with accepted different value of $1 \%-10 \%$ ).

- In comparing Distribution Similarity, the Distribution of Percentage Value always give beter and correct answer, compare to the Distribution of Real Value. Thus, comparaison of Distribution Similarity must be based on the Percentage Value Distribution.

- It is better to name the method as Distribution Similarity Test based on Accepted Curve Pattern Similarity and Absolute Value Difference (Accepted CPS+AVD).

After finishing this researchs a certain further curiousity arose, i.e. to test the Method for Diferent Real Cases.

NOTE. This paper is a part of Working Papers for developing the Knowledge and Science of Infrastructure \& Facility Asset Management. This paper is a result of reflection collaboration among a Statistician and Civil Engineers from Institut Teknologi Sepuluh Nopember (ITS), Surabaya, Indonesia.

\section{REFERENCES}

Avecedo, C.R. \& Nohara, J. (2004). Consumer behaviorius Tourism: A Study with Senior Tourists. Anais do Il Seminario de Presquisa em Tourismo do Mercosul, 10-11 Setembro de 2004.

Blank, L. (1982). Statistical Procedures for Engineering, Management, and Science. International Student Edition. Mc-Graw Hill International Book Company. Tokyo.

Chilongola, F.D., Suprayitno, H. \& Dewanti (2020). "Preliminary Research on Air Passenger Volume Variation in Kilimanjaro Airport Tanzania”. Journal of Infrastructure \& Facility Asset Management, 2(2) September 2020.

Engmann, S. \& Cousineau, D. (2011) Comparing Distributions: The Two Samples AndersonDarling Test as An Alternative to The Kolmogorof-Smirnoff Test. Journal of Applied Quantitative Method, 6(3) Fall 2011.

Hamzah, Dewanti \& Muthohar, I. (2020). Evaluasi Peningkatan Pelayanan Terminal Bandara Kelas I Mopah Merauke. Jurnal Manajemen Aset Infrastruktur \& Fasilitas 4(2), April 2020, 91-106.

Purwanto, E.A. \& Sulistyastuti, D.R. (2017). Metoda Penelitian Kuantitatif untuk Administrasi Publik dan Masalah-Masalah Sosial. Edisi 2. Penerbit Gava Media. Yogyakarta.

Siegel, S. (1956). Nonparametric Statistics for the Behavioral Sciences. International Student Edition. McGraw-Hill Book Company, Inc. \& Kogakusha Company, Ltd. Tokyo.

Siregar, S. (2016). Statistika Deskriptif untuk Penelitian. Cetakan Ke-lima. PT Raja Grafindo Perkasa. Jakarta.

Soemitro, R.A.A. \& Suprayitno, H. (2018). Pemikiran Awal tentang Prinsip Dasar Manajemen Aset Fasilitas. Jurnal Manajemen Aset Infrastruktur \& Fasilitas, 2(Sup1) Juni 2018.

Suprayitno, H. (2020). Developing a Direct Gravity Trip Distribution Model for Air Passenger Demand. IOP Conference Series: Earth and Environmental Science, 419012092.

Suprayitno, H., Irlambang, D., Pramono, Y.A. \& Wibowo, A.G. (2006). Karakterisitk Penumpang dan Perjalanana pada KA Penumpang Ekonomi di Wilayah Gerbangkertosusila. Jurnal Teknobisnis 2(1), Juli 2006: 41-48.

Suprayitno, H., Pambudi, E.K. \& Cahyono, M.S.D. (2017). "Preliminary Modeling for Ship Passenger Arrival Distribution - Case of Gapura Surya Nusantara Passenger Terminal, 
Tanjung Perak Perak Port, Surabaya". Proceeding of the Eastern Asia Society for Transportation Studies (EASTS), Vol. 11, 2017.

Suprayitno, H., Ratnasari, V. \& Saraswati, N. (2017). Experiment Design for Determining the

Minimum Sample Size for Developing Sample Based Trip Length Distribution. IOP

Conference Series: Material Science and Engineering 267 (2017) 012029.

Suprayitno, H., Ratnasari, V., Saraswati, N. \& Fajriani, C.P. (2018). Sample Based Trip Length Distribution Quality based on $\chi^{2}$ and Mean Absolute Error Value. IPTEK - Journal for Technology and Science 29(1), 5-101.

Suprayitno, H. \& Soemitro, R.A.A. (2018). Preliminary Reflexion on Basic Principle of Infrastructure Asset Management. Jurnal Manajemen Aset Infrstruktur \& Fasilitas, 2(1) Maret 2018.

Susanti, A., Soemitro, R.A.A. \& Suprayitno, H. (2019). "Comparative Analysis on Access and Egress Distances for Semi BRT Trans Mamminasata and Commuter Train Susi”. IOP Conf. Series: Earth and Environmental Sceince 340 (2019) 012005.

Susanti, A., Soemitro, R.A.A. \& Suprayitno, H. (2020). "Perbandingan dan Sintesa Karakterisitik Perilaku Perjalanan Penumpang KA Komuter SULAM dan KA Komuter SUPOR”. Jurnal Manajemen Aset Infrastruktur \& Fasilitas 4(3), Juli 2020, 261-272.

Susanti, A., Suprayitno, H. \& Soemitro, R.A.A. (2017). Wilayah Pengaruh Kereta Api Komuter terhadap Pengguna Sepeda Motor di Kota Surabaya. Jurnal Transportasi, 17(3), Desember 2017, 235-244.

Susetyo, B. (2010). Statistika untuk Analisis Data Penelitian. Cetakan Ke-empat. PT Refika Aditama. Bandung.

Upa, V.A. \& Setyadi, R. (2020). Analisis Karakterisitk Penggunaan Bus BSD Link untuk Disain Koridor Baru Menggunakan Model Permintaan Perjalanana. Politeknologi 19(1) Januari 2020.

Upa, V.A., Suprayitno, H. \& Ryansyah, M. (2018). Perbandingan dan Sintesis Karakteristik Perilaku Perjalanan Pengguna Bis Trans Mamminasata dan Trans Koetaradja. Jurnal Manajemen Aset Infrastruktur \& Fasilitas 2(2) September 2018, hal. 69-81.

Valguna, P.A., Dewanti \& Suparma, L.B. (2020). Dampak Perkembangan Pariwisata Pulau Lombok terhadap Pengembangan Bandar Udara Internasional Lombok. Jurnal Manajemen Aset Infrastruktur \& Fasilitas 4(3), Juli2020, 195-210. 